\title{
CINEMA-EXPERIÊNCIA E OS ENCONTROS DA IMAGEM COM A EDUCAÇÃO
}

CINEMA-EXPERIENCE AND IMAGE ENCOUNTERS WITH EDUCATION

CINEMA-EXPERIENCIA Y LOS ENCUENTROS DE LA IMAGEN CON LA EDUCACIÓN

ANTUNES, Thiago 1

ALVES, Karina 2

MORAES, Thereza ${ }^{3}$

\section{RESUMO}

Entendendo o trabalho com imagens como um exercício político, filosófico e estético, encaramos nossas experiências com Cinema-Educação. Perseguindo a questão “a que tipo de imagens nosso conhecimento pedagógico dá lugar?”, procuramos ensaiar formas de lidar com o Cinema-Educação a partir da im agem do Maloqueiro e das noções de Montagem e Cinema-Experiência.

Palavras-chave: Cinema-Experiência. Cinema-Educação. Montagem. Maloqueiro.

\section{ABSTRACT}

Understanding working with images as a political, philosophical and aesthetic exercise, we face our experiences with CinemaEducation. Pursuing the question "what kind of images does our pedagogical knowledge give rise to?", We try to rehearse ways of dealing with Cinema-Education from the image of the Maloqueiro and from the notions of Editing and Cinema-Experience.

Keywords: Cinema-Experience. Cinema-Education. Editing. Maloqueiro.

\section{RESUMEN}

Entendiendo el trabajo con imágenes como un ejercicio político, filosófico y estético, enfrentamos nuestras experiencias con Cinema-Education. Siguiendo la pregunta "¿a qué tipo de imágenes da lugar nuestro conocimiento pedagógico?", Tratamos de ensayar formas de tratar con Cinema-Education a partir de la imagen del Maloqueiro y de las nociones de Montaje y CinemaExperiencia.

Palabras clave: Cinema-Experiencia. Educación cinematográfica. Montaje. Maloqueiro.

\footnotetext{
${ }^{1}$ Universidade Federal de Pernambuco - UFPE - Recife/PE - Brasil.

${ }^{2}$ Universidade Federal de Pernambuco - UFPE - Recife/PE - Brasil.

${ }^{3}$ Universidade Federal de Pernambuco - UFPE - Recife/PE - Brasil.
} 


\section{AO ENCONTRO DA IMAGEM}

O trabalho com as imagens na educação é, antes de tudo, uma labuta política. Começamos a suspeitar disso nas diversas disciplinas em que tentamos colocar o cinema como parte do currículo dos cursos de licenciatura em uma universidade. Leia-se: experimentamos introduzi-lo não como adereço ou suporte, mas, sim como linguagem que dá a saber alguma coisa. Os mais diversos estranhamentos nos surgiam: "estamos nos formando professores ou cineastas?", questionavam os estudantes das diversas salas de aula. Entre as idas e vindas em nosso percurso, os estudantes - e mesmo outros colegas - nos perguntavam inúmeras vezes sobre nosso método, ou sobre como lidamos com a imagem. Na busca por certa objetividade com relação a elas, sempre fracassamos.

Porque as imagens de Cinema ou audiovisuais são relativamente novas na educação. E como qualquer novidade, tais contatos produzem fricções que acabam por formular outros entendimentos e estranhamentos. Desconfortos que só a novidade - no sentido mais infante do termo - podem propositar. Percebemos que esses contatos produzem experiências híbridas, que deixam ver dois tempos diferentes em um só plano: o tempo das imagens e o tempo da educação. Sim, porque a educação, falamos, aqui, especialmente, em educação escolar, tem uma temporalidade própria e propícia à sua linguagem. O tempo da fala do professor, por exemplo, ou tempo da leitura e da escrita. Mas a partir do momento em que o tempo da imagem audiovisual - vintequatro frames por segundo afeta a educação, um terceiro tempo se instaura.

Temos acompanhado (acompanhado o que?), de certa forma, os estudos imagéticos e cinematográficos nos levarem a questões importantes. A primeira delas é o imperativo das imagens no nosso tempo. E não é difícil de se verificar tal premissa: a imagem, hoje, circula entre nós quase "organicamente". Outdoors, folhetos, banners, vídeoaulas, short movies para Youtube, Instagram, Facebook, Whatsapp, fotografias, propagandas, memes... estamos inundados pelas imagens. O tempo dos textos - de leitura e de produção - dá lugar a um tempo da imagem - da mídia, principalmente.

Se, por um lado, nesta feita, a escola e a universidade são lugares propícios para acesso a filmes que estão fora de certo circuito comercial e midiático, por outro, ocorre que facilmente o cinema pode se tornar uma simples ferramenta didática nas mãos daqueles que a usam para "ensinar" conteúdos curriculares (e/ou "examiná-los" diretivamente, sugiro excluir), como se o cinema fosse, somente, uma ferramenta a ser usada com o propósito de diversificar os métodos escolares.

Foi, então, que acentuamos nosso compromisso político. Porque pensamos contrariamente aos que querem usar o cinema para propósitos simplesmente instrumentais: as experiências híbridas de Cinema-Educação, para nós, podem produzir novos efeitos imagéticos e, ao mesmo tempo, novos efeitos educativos. Chamamos isso, em algum momento, de Cinema-Experiência. Uma imagem que não mais dá suporte a um texto da cartilha do professor, mas permite a criação de imagens com carne e osso, produções em que aqueles habitam as relações da educação podem estar presentes. $\mathrm{O}$ caso da permanência das imagens: aquilo que está gravado pode não desaparecer.

Didi-Huberman, em seu artigo "Quando as imagens tocam o real", persegue uma questão inquietante: "a que tipo de conhecimento pode dar lugar a imagem?" (2012, p. 207). Gostaríamos de 
retomar essa questão, profanando-a um pouco. De certa forma gostaríamos de trazê-la para nosso campo de investigação. Podemos perguntar, então: a que tipo de imagens nosso conhecimento pedagógico - dá lugar? A saber, sobre que princípios temos lidado com as imagens em educação?

Neste fio vermelho e com base em nossas últimas pesquisas, resolvemos pensar como temos nos relacionado com as imagens na educação. É objetivo deste trabalho ensaiar sobre alguns princípios de como tratamos ou poderíamos tratar as imagens em educação. Para tanto, construímos este ensaio em quatro tons ou frequências para nos aproximarmos um tanto do que chamamos Cinema-Experiência nessas experiências híbridas de Cinema-Educação. Gostaríamos de exercitar um pouco o que chamamos de pensar por imagens, recolher forças em suas potências.

Por isto, num primeiro momento, tentamos colocar melhor nosso problema. Apresentando, en passant, qual a geopolítica dos territórios sobre os quais nos colocamos. Especificamente, gostaríamos de justificar a necessidade de certa atenção ao tema, a partir de alguns achados de nossa pesquisa de Estado da Arte, situando o debate em dois modos de presença do Cinema-Educação. Num segundo momento, no entanto, gostaríamos de apresentar uma imagem que nos inspira e que se pode encontrar nos becos e vielas de nossa cidade: o maloqueiro. Quisemos expor pensamos que reverberam certa ética contra-política do trato das imagens. Por último, apresentamos a montagem, aquilo que, para nós, é uma atitude corriqueira dos maloqueiros, mas que podem ser trazidas à tona por certa maneira de pensar a imagem: um cuidado com as imagens, manifestando o que nosso conhecimento pode dar a ver com e nas imagens, através e por elas. Esse cuidado, para nós, reforça aquilo que chamamos Cinema-Experiência e agencia um terceiro modo de presença que, para nós, apresenta uma outra imagem possível do nosso conhecimento pedagógico: uma imagem menor.

\section{CINEMA-EDUCAÇÃO EM DOIS MODOS DE PRESENÇA}

Entre os meses de outubro e dezembro de 2018, realizamos uma pesquisa de Estado da Arte que se iniciou com a busca, no portal de periódicos da CAPES, dos termos intercruzados: Cinema e Educação. Encontramos, ao longo dos últimos vinte anos, uma produção crescente de artigos, dossiês, ensaios, resumos e resenhas que totalizou 85 trabalhos. Destes, 30 foram publicados entre os anos 2000 - 2010 e os outros 55 entre os anos de 2011 - 2018. Embora não seja, para a área de educação, uma produção massiva de textos sobre o tema, consideramos uma amostra significativa para pensarmos a emergência dos discursos sobre Cinema-Educação.

Salientamos que há um crescimento da demanda de discussão da relação entre cinema e educação impulsionada pela criação da lei de Cinema na Escola, proposta pelo Senador Cristovam Buarque em 2008, aprovada e incorporada a LDB 9394/96 em 2014. Embora não seja nova a ideia de exibir produções em sala de aula, a lei regulamenta a obrigatoriedade da reprodução de duas horas mensais de filmes nacionais. A necessidade gerada, embora ainda pouco discutida e conhecida, cria nos professores um reposicionamento em relação à prática instituída. Ou seja, há uma reconfiguração no campo de saber que permite a inserção de pesquisadores e teóricos nesta disputa. Ora, o estado da arte, nesse pressuposto, se tornou também uma excelente oportunidade para pensar como se montam 
as geopolíticas encaradas na área, principalmente quando nos demos conta que 41 dos trabalhos foram realizados por pesquisadores do sudeste e, a contraponto, apenas 5 no nordeste e 1 no norte do país. Esse desnível em relações quantitativas rebate, também, em outras questões.

Pernambuco, o estado no qual nos situamos, possui uma efervescente produção cinematográfica reconhecida internacionalmente. Contudo, por exemplo, a Secretaria de Educação de Pernambuco criou, em 2017, as Orientações Pedagógicas do uso de Cinema Brasileiro Contemporâneo na Escola, com o intuito de trabalhar as "Caixas de Filmes" produzidas e distribuídas nas escolas do estado pela Globo Filmes. Em nenhum momento há registros de filmes feitos por pernambucanos ou debatendo o filme como artec, menos ainda apresenta propostas para o fazer filmico. Ao se referir à alguns filmes, por exemplo, o próprio documento orienta a não exibição por conteúdo impróprio.

Diante deste cenário e acompanhando o debate que se instaura nos artigos, resolvemos analisá-los mais qualitativamente. Exploramos, então, suas temáticas, objetivos e os argumentos que utilizavam para operar a junção entre Cinema e Educação. Neste sentido, optamos por dividi-los em dois grupos argumentativos, que refletem dois modos de presença na relação entre cinema e educação dentro e fora do espaço escolar: o primeiro refere-se ao cinema como didática, o segundo ao cinemaeducação como experimentação de pensamento.

O cinema como didática é uma via de mão dupla: o cinema como instrumento para a educação e/ou a educação como possibilidade de ensinar cinema. O primeiro, mais encontrado entre os professores e pedagogos, o segundo encarado por comunicólogos e cineastas. No entanto, o cerne da questão é que o cinema, para esses, poderia ensinar melhor e o filme seria

\begin{abstract}
Instrumento metodológico de excelência no ensino... não substitui de todo a observação direta... contudo apresenta uma perspectiva interessante sobre a relação entre dados recolhidos na realidade, em estreita relação com a visão do realizador... numa ambivalência também constituída pelo olhar do espectador, neste caso do professor, o qual aproveita tal recurso com propósitos didáticos. ( VIEIRA, VELEZ, 2016, p. 308, grifo nosso).
\end{abstract}

Há uma crença genuína na possibilidade e necessidade de renovação escolar, pedagógica e metodológica nesse caso. Tal transformação passaria pelo currículo, para emergir em problemas que, talvez, o currículo não dá conta: fazer com que a operação escolar tenha sentido e seja "divertida" ou "atrativa". Em termos de intencionalidade, o cinema iria suprir as faltas da escola, como afirmam Thomaz e Mattos (2015, p. 225):

o universo das representações sociais existentes... requer um poder imaginativo que nos é suprido através da pelicula cinematográfica. O cinema tem o poder de fazer o telespectador vivenciar experiências, sensações e emoções adormecidas e com as quais não dialoga por não ter essas vivências em seu cotidiano.

Tenta-se, então, de usar o cinema e o "trabalho com filmes" para que os alunos aprendam melhor os mesmos conteúdos consagrados, dentro dos mesmos formatos disciplinares, com a roupagem de uma nova proposta, inclusive a como viver em um "novo mundo", com "novas demandas", "novas tecnologias"... Mas, com o velho desejo de representação, como se o cinema 
mostrasse melhor, pudesse expor " $A$ verdade". Entendem, portanto, ensinar como "uma atividade consciente e objetiva, que se pretende até mesmo científica, na qual seria possível determinar quais métodos são melhores para fazer as pessoas aprenderem conteúdos específicos" (COUTINHO, 2013, p. 20). Esse é o tom dos que pretendem formar para o cinema ou em usar o cinema na formação.

Há, em tal construção teórica, uma necessidade de operar pela mediação ou pela tutela. Fazer - no sentido impositivo e imperativo do termo - com que os alunos falem alguma coisa, ou pensem outras coisas. Molleta apresenta como objetivo de seu livro e proposição didática para o ensino com cinema:

\footnotetext{
organizar o potencial de criação e de conhecimento que os jovens, há muito, vêm adquirindo... transformar esse potencial em expressão artística, social e - por que não? - educacional... dando-Ihes oportunidade de ser protagonistas de seu aprendizado. (MOLLETA, 2014, p. 10).
}

Supõe o professor como aquele que sabe, aquele que viu além de seus alunos e pode lhes dizer o caminho, pode transformar, mudar essa raiz forte e cultural num protagonismo que lhes falta e que sobra no professor: transposição didática, interlocução do saber com a realidade... tais foram os nomes que alguns pedagogos deram.

Sim, a escola e universidade são lugares privilegiados de acesso coletivo ao cinema que foge, minimamente, do consumo hegemônico. Por outro lado, a escola se apresenta como o lugar tradicional do ensino, da regra e da transmissão de padrões estabilizados de cultura. Isso conduz ao paradoxo próprio do encontro do cinema com a escola. É possível pensar uma relação CinemaEducação que não sacrifique o cinema como uma experiência? É possível ativar a força perturbadora da criação em um contexto de normalização e homogeneização? Tais questões enviam à necessidade de questionar a didatização do cinema, tanto quanto a questionar a necessidade de um "treinamento" para entendimento do cinema. O cinema, assim, no modo didático de presença, se marca pela sua ausência como cinema: como instrumento para "ilustrar", "exemplificar", "explicar", "transmitir" os "verdadeiros conteúdos", os conceitos das matérias escolares, o cinema aparece para desaparecer.

A didática, vimos, ensina. Já o Cinema-Educação como experimentação filosófica apela para os saberes estéticos. O saber estético, veremos, sente.

Sentir pode ser educativo e formativo, mas esse não é seu objetivo. Sentimos para fruir, degustar, experienciar... Assim bailam os que acreditam em algo de feroz e selvagem no cinema. Aquele que se aproxima do cinema e da educação, nessa perspectiva,

por mais desatento ou seguro que seja em sua aproximação, deixa-se envolver naquilo que nem sempre o filme explicita... pode ser tomado por uma força misteriosa, experimentando uma sensação de distanciamento em relação àquilo que é proposto. $E$ uma quebra de regras que se pode captar o instante, como se janelas que se abrem para o inusitado e o insignificante retirassem dali os elementos da significância. (FANTIN, 2013, p. 543-544).

A didática já não tem mais nada o que fazer com os filmes, pois o que importa é justo o que o eles não podem dizer. Não necessariamente o explícito importa, mas dá lugar ao arranjo estético, ao conjunto que é supra-narrativo. A história contada ganha a mesma importância que os outros elementos filmográficos. Também não há nada a ser desvelado, revelado, explicado. 
Cinema que está sob risco, assim como a educação que o segue. É uma marca deste modo de presença encarar o Cinema e Educação como palco de resistência contra "o sucateamento dos espaços públicos" (FRESQUET; PEREIRA, 2018, p. 170) e a "pedagogização da existência... uma espécie de contraponto aos modos acelerados de comunicação que vivemos hoje" (Ibidem, p. 172). Uma relação ética e estética justamente por se tratar de uma relação política, "esgarçando fronteiras, produzindo polifonias, alterando espaços, tempos..." (DUARTE et al, 2018, p. 203). Um CinemaEducação que busca a imagem da diferença e portanto, se distancia enormemente do modo de presença didático. Entende, verdadeiramente, que há "muito mais coisas na vida do que supõe nosso restrito (e arrogante!) conhecimento dela" (Ibidem, p. 204).

Nesta perspectiva, a imagem de cinema "é intrinsecamente ligada ao mundo, ela sofre o mundo, é afetada pelo real... por outro ele é alteração... uma transformação continua do que há... instala-se na insegurança, estranhamento e instabilidade da criação" (MIGLIORIN, 2010, p. 109). Aí é que está: Cinema-Educação num duplo jogo que pode criar um outro mundo, ao passo que não esquece o mundo em que vive. Isso que chamamos de práticas híbridas está plenamente consonante aqui.

Quando encontra com possibilidade de pensar imagética, advinda da posição política do filme como diferença e devir, a educação pode ofertar contra-imaginários. Quem irrompe a realidade-cinema e abandona a perseguição do que o filme gostaria de dizer, pode atravessar vetores de múltiplos sentimentos nas imagens e deixa emergir uma experiência subjetividade-filme - não uma experiência subjetiva do filme - produzindo o filme-coletivo ou um filme-nós, incrustado em modos coletivos de escancarar e cascavilhar outros mundos. Dar a qualquer filme o sopro do local e a qualquer local o sopro do encontro que tivemos com aquele filme. Trata-se de do abandono de todas as tentativas de universalização, fechamento do social e de toda a paranóia conciliadora. Pensar que, talvez, as soluções do local, o sopro de vida e o conhecimento visceral de causa podem ser explorados.

Já não se pode, então, fazer ciência com que caminham entre a ética e estética, uma vez encontrado com o que se sente e com o risco do real. Só se aposta na alteridade e na diferença, na profusão de questões - mais até do que soluções - para então multiplicar encontros amorosos com a imagem. Surge, então, um modo próprio de afetação do Cinema-Educação, que dá a pensar questões como: o que pode o cinema? O que dá a ver nosso conhecimento? O quanto apostamos na potência criadora e crítica das imagens?

Podemos dizer que nossa tentativa é nos aproximarmos do Cinema-Educação como modo de experimentar o pensamento. Por isso, no que segue, tentaremos ensaiar nossas maneiras de vivenciar o que chamamos Cinema-Experiência. Diretivamente, agora, apresentamos a imagem do maloqueiro. Em um exercício poético e imagético, gostaríamos de reverberar certos elementos éticos e estéticos que nos fazem pensar como o Cinema-Experiência lida com as suas montagens.

\section{MALOQUEIRO: FRAGMENTOS DE UMA IMAGEM POÉTICA}


Para nosso trabalho com as imagens, para chegar ao que chamamos de montagem, foi necessário insinuar certa maloqueiragem, uma dessas palavras sujas e profanas que circundam nossa cidade. Há algo de múltiplo e inquietante nessa figura que encarna uma política do léxico, que faz dele, ao mesmo tempo, o que se esgueira na cidade e a cidade que se esgueira.

Ele não é o squartter ou o deadbeat inglês - que ocupa um prédio ou uma parte da cidade que não é dele legalmente; caloteiro, não confiável, furtador... Não é o Vagabundo ou o Embusteiro espanhol - que não tem residência fixa, que mora na rua e comete pequenos delitos; mentiroso, trapaceiro, traidor... Nem é o PickPocket ou Délinquant francês - que comete pequenos assaltos, batedor de carteiras; que não segue as leis... Também não se trata do Malandro ou o Velhaco carioca - esperto e caricato, que rouba nos jogos, não paga suas dívidas, que gosta da "vida fácil”...

Maloqueiro aproxima-se ao Mandingueiro (MESQUITA, 2019, no prelo). Essa figura que está incorporada na mandinga, nesse "coração batendo" (Ibidem, p. 72, no prelo), nessa vitalidade teimosa e abestalhada, que se apresenta como memória de uma existência e resistência anterior à colonização. A sua "presença contínua enseja valores e padrões de sociabilidade que evidenciam um hiato radical entre tipos imprevisíveis de sujeito ético que podem daí emergir" (Ibidem, p. 78, no prelo.). Esse é o chão: o maloqueiro pode ter mandinga, um mandingueiro pode ter maloqueiragem; mas a maloqueiragem é jovem e citadina, a mandinga é ancestral e descontínua. O maloqueiro ainda mostra os espinhos que o mandingueiro aprendeu a esconder.

O maloqueiro é sim um marginal, principalmente em seu atributo físico. É um dos que passam despercebidos pela borda - à noite chega a ser imperceptível. Aprendeu a agilidade que as ruas pedem. Tem seu lugar de emergência na cidade: essas zonas urbanas que compartilham proximidades não complementares, divididas por vetores sociais aos quais todos estão desapercebidamente a par. Em uma cidade como Recife, há pelo menos duas cidades: "uma cidade sólida, toda de pedra e ferro... iluminada, asfaltada, onde os caixotes do lixo regurgitam de sobras desconhecidas, jamais vistas, nem mesmo sondadas... saciada, indolente, de brancos. Estrangeiros” (FANON, 2013, p. 48). Enquanto a outra "é um lugar mal afamado, povoado de homens mal afamados. Aí se nasce não importa onde, não importa como. Morre-se não importa onde, não importa de quê... uma cidade acordada, uma cidade ajoelhada, uma cidade acuada" (Ibidem, p. 48).

Manhã após manhã, os habitantes da segunda zona seguem para a primeira: da cidade dos servos para a cidade dos servidos. Para trabalhar, como "cidadãos de bem", ou para pedir esmolas, como "necessitados e desafortunados". Do Mucambo para o Sobrado. Da Senzala para a Casa Grande. Da periferia para o Centro. O maloqueiro, do contrário, transita entre essas duas cidades porque nenhuma das duas lhe pertence realmente: ele pode trabalhar eventualmente, mas nunca será visto como um cidadão de bem; ele pede esmolas, mas carrega um tom de desdém e deboche. Ele só conhece a borda, a rua. Foi expulso do céu e do inferno. A periferia, normalmente, não gosta dele - é constantemente o exemplo de jovem imoral que as mães dão aos seus filhos. $O$ centro também não gosta dele - é considerado, com razão, uma ameaça. Sobrevive na ordem, mesmo estando fora da ordem.

Nômade como o que é produtivo (FOUCAULT, 1993). Mesmo que tenha casa, perambula de dia e de noite. São os que entram nos ônibus sem pagar, pedem carona, zigzagueam numa bicicleta 
ou remam em barcos velhos. Frequentemente dormem em prédios abandonados, debaixo de marquises ou nas casas provisórias de conhecidos. O maloqueiro, então, emburaca: prefere entrar pelos buracos, pelas pequenas fendas, pelos caminhos difíceis e não pela porta, pelo lugar da clareza, lugar autorizado.

Devido a sua errância o maloqueiro é caçador e coletor. Circula entre os bolsões férteis da cidade atrás de coisas interessantes: pequenos objetos brilhantes, oportunidades de diversão gastas, horas de vadiagem programáticas em frente a lugares onde pessoas de bem gastam suas vidas trabalhando. A ação do maloqueiro é malocar. guardar, esconder, ocultar - daí pergunta: 0 que tu malocou aí? - ao mesmo tempo que maloca significa o lugar de habitação, o conjunto de ocas, o lugar dos Caboclos. Como usualmente não tem casa fixa, carrega somente aquilo que seu próprio corpo consegue levar. O maloqueiro, então, entoca: põe na toca, guarda e esconde tudo o que consegue. Guarda tantas coisas, em tantos lugares, que chega a esquecer do que possui. Suas tocas são os diversos buracos de prédios e terrenos em que ele confia e volta muitas vezes. O maloqueiro gera um circuito paralelo, próprio à cidade, onde nunca se pode ver o fim, um devir lugar - não é estranho que se diga, entre os maloqueiros "vou chegar" no sentido de "estou indo embora". Na profusão tocas, o que importa está sempre mais à frente.

Essa é a natureza da maloqueiragem: a gambiarra, a pirataria, o atalho, a montagem. Ele pode operar, pelo advento de sua experiência, com todas as coisas que guarda em si para produzir mundos, ou para ajudar no seu trânsito por outros mundos. Ela é uma leitura, mas, não a da escola, da regra, da lei. Uma leitura imagética: a visualidade da demanda, o mapa da guerra e a cartografia da cidade. Só conhece o signo e a imagem: a cor dos ônibus, a paisagem do destino, o brilho dos objetos, a distância do pulo, o trajeto da mão, os tamanhos, as formas, o desenho. Ele então vaza - sai rapidamente, quase sem ser percebido. Põe pra fora aquilo que entocou. Por isso pixa. Marca com uma gramática visual que só ele conhece: um agenciamento coletivo de enunciação, uma língua maloqueira com regras difusas, confusas, novas. Um signo territorial esdrúxulo, quase como uma língua morta. Os muros da cidade, cobertos por pichações, são seus atestados de vida, seu testamento e seu memorial - Não é incomum ler, ao lado de uma assinatura de pixação, apelidos de companheiros de rua que se foram. Camada após camada o maloqueiro inscreve a cidade como palimpsesto.

Ele desafia a limpeza, a clareza e o raciocínio lógico com seu coletivo, pois não há maloqueiros fora do bando, - se o anômalo deleuziano é aquele que está tão a borda e ao mesmo tempo tão a par da situação de sua espécie, sendo o próprio fenômeno da borda ao ponto de que pode ocupar um corpo impossível - a maloqueiragem e o maloqueiro são experiências e a subjetividades coletivas que recolocam jovens somente marginalizados - que poderiam estar em qualquer um dos países que foram colonizados - de volta para a sua política de fuga dos padrões de abjeto ou aceito, para o vetor de desterritorialização de identidades fixadas e conhecidas pelo colonizador. Os maloqueiros abrem a cidade com os pés. Escolhem a cidade com suas mãos. Entocam a cidade em seus bolsos. Carregam a cidade consigo quando pulam de uma ponte. Desafiam a cidade, como suas braçadas contra a corrente do rio.

Por que foi lançado nessa vida em condições adversas, o maloqueiro contra-lança seu corpo numa feroz tentativa de existir livremente. Um desejo de vida frequentemente marcados: cicatrizes de 
objetos cortantes, quedas, topadas, brigas... ou com tatuagens de estética suja, abjeta, marginal. Seu corpo é um corpo comum, um corpo comunitário, fabricado pela experiência-maloqueiragem, constituído na pura empiria, é um artefato histórico da produção dessa subjetividade coletiva pautada no desafio: essa é a maloqueiragem do cantador que sobe no ônibus para cantar um Coco e tirar o sustento do dia, dos meninos que pulam no rio sujo e pescam com vara curta, do garoto que faz frete, que trabalha na feira, que vende comida na praia, que perambula atrás de furtos no centro, que vende balas no metrô, que vive dia após dia.

Poderíamos, talvez, dizer que o maloqueiro é o recalque da cidade: aquele que é expulso pela porta dos fundos e ressurge poderosamente pela porta da frente. A maior ilegalidade que ele comete é estar vivo diante do estado de exceção que seu povo foi posto. Ele está plenamente ciente que querem o prender e matar, que querem seu fim, mas "não se impõe a lei a quem arrisca seu corpo diante um poder" (FOUCAULT, 2017). Ele permanece fantasmando os espaços.

\section{MONTAGEM: UMA TEORIA MALOQUEIRA DA IMAGEM}

A imagem põe em relação o tempo, quem nós somos ou estamos e quem poderíamos, talvez, ser no tempo. De fato, isso nos encanta no cinema. Alguns o chamaram de arte das massas, arte do povo: de fato o é. "O cinema é uma arte das massas porque transforma o tempo em percepção, torna o tempo visível e, assim, cria um sentimento do tempo, o que não é o mesmo que o tempo vivido" (BADIOU, 2015, p. 39). Ao contrário desse tempo vivido, quem faz o filme interrompe o mundo, coloca as horas e os minutos que nos separam - geográfica e afetivamente - para vermos. Exatamente como o maloqueiro faz.

Não se trata somente do cinema. Há uma mudança nas nossas maneiras de dizer, ver e pensar o tempo e o mundo, onde os cineastas e fotógrafos não possuem mais sequer a ideia de prioridade no uso das imagens. Das telas dos nossos celulares, televisores, computadores, tablets, das projeções de cinema, de propaganda, dos letreiros eletrônicos... observamos a incorporação das tecnologias audiovisuais em nossa organicidade de mundo - para além do simples suporte - como algo que constitui, manifesta e transforma nossos modos de viver, de lidar com as informações que nos chegam e com a produção vertiginosa do que chamamos realidade. Habitar o mundo e ver a imagem que nos espreita: "nunca, portanto... a imagem sofreu tantos dilaceramentos, tantas reivindicações contraditórias e tantas rejeições cruzadas, manipulações imorais e execrações moralizantes" (DIDIHUBERMAN, 2012, p. 209).

Teremos que lidar, parte agora e de certo nas próximas gerações, com as transformações corporais e epistemológicas que isso nos impõe. Especificamente para nós na docência, é impossível ignorar todas as demandas que as diferente imagens nos fazem, além das disputas e démarches encenadas por ocasião. Reagimos a um tempo que é mais do que puro cronos, que pura passagem de momentos: "tempo como construção e montagem, e o tempo como dilatação da imobilidade" (BADIOU, 2015, p. 46), que salta aos olhos e é vivido, de fato, por aqueles que estão livres de certas obrigações: maloqueiros - cujo tempo e a vida são gastas de outra forma que não na lógica do trabalho e do 
atraso; as crianças - que só conseguem contar o tempo de acontecimento em acontecimento; idosos em asilos - que não sentem mais o tempo passar e se apegam só àquilo que está na memória...

Um tempo montado em uma imagem montada. É lá, no tempo, em que a imagem e a narrativa se tocam: as possibilidades de dizermos tais e quais coisas que dissemos - ou diremos - é situada. O menor movimento de tensionar e deslocar a linguagem um pouco mais além, para falar outra coisa - ou a mesma coisa de uma outra forma - assemelha-se a "traçar para a linguagem uma espécie de linha de fuga" (DELEUZE, 2013, p. 58). Narrar no sentido de 'narrare', "algo assim como 'arrastar para a frente', e que deriva também de 'gnarus' que é, ao mesmo tempo, 'o que sabe' e 'o que viu'... O que narra é o que leva para frente, apresentando-o de novo, o que viu e do qual conserva um rastro em sua memória" (LARROSA, 1994). Esta é uma atitude maloqueira: materializar o tempo, porque não conhece cronos. O tempo como pura passagem não lhe diz muita coisa: porque não trabalha, não estuda, não tem compromissos ou agendas, o maloqueiro está livre da percepção de tempo ordinário. Não é difícil ouvir um maloqueiro falar de situações ocorridas há cinco ou dez anos como se tivessem presentes. Um passado intencionado na imagem presente (BENJAMIN, 2012). Um presente que cria, porque seleciona, não mostra tudo, faz a bricolagem, o jogo.

É mais ou menos como maloqueiros entram em contato com certas imagens: como quem procura "pelos nomes e fórmulas que lhe saltem aos olhos" (BENJAMIN, 2013, p. 127), para então encontrar expressões e palavras onde "o sentido é apenas o plano de fundo sobre o qual pousa a sombra que elas projetam como figuras em relevo" (Ibdem, p. 127). Uma narrativa "como forma artesanal de comunicação" - um Cinema-Experiência evoca o cinema de montagem. Esse processo pelo qual a escritura passa antes de ser escritura e um filme passa antes de ser filme... Montagem. Tendo entocado o quanto pôde, o maloqueiro - quem monta - tem um arsenal de incontáveis coisas inúteis que pode vazar, 'retirar' de dentro de si e operar com elas.

É isso que chamamos montagem. fazer com que transitem, na mesma visualidade, tudo aquilo que deve ser mostrado, contrastando com o que não pode e não vai ser; poder tomar as decisões baseado no que é o objeto de desejo. Não se trata de fazer com que as imagens ganhem um "sentido" e sim de fazê-las operar em conjunto na difusão de sentimentos e políticas que possam engendrar novas metáforas que propagam diferenças, como feixe de articulações que compõem regimes de dizibilidade/visibilidade, maneiras de ver e a dar a ver, projetando uma nova visualidade do que tomamos por "real". No fim, um elogio da montagem é o entendimento de que o objeto montado e o sujeito que monta são um só.

Falar em montagem é remeter a uma fabricação com recursos imagéticos, - fotografias, vídeos, pinturas, gravuras... - mas o que aqui evocamos está ligado não somente aos signos visuais e sim para toda a produção de significação, que "não cessam de agir e de reagir entre si, de produzir e de consumir. Não há diferença alguma entre as imagens, as coisas e os movimentos" (DELEUZE, 2013, p. 59). Isso requer entender que as palavras e sons também são produtoras de uma visualidade, por mais que não sejam materiais necessariamente "olháveis". A montagem é, antes de mais nada, tentar ver de trás para a frente: "o poder de antecipar um efeito para melhor deslocá-lo ou contradizêIo" (RANCIERE, 2012, p. 14), ou reafirmar, estender e exteriorizar e desmantelar os sentidos. É, também, a escolha do que se deve usar para dizer, ao mesmo tempo que o processo de descoberta e 
criação do que se quer dizer. Imagem como uma relação viva, social e localizada no tempo a qual pertence e ao qual alcançará, rompendo com as interpretações da pura técnica e com a separação da imagem (criação virtual) da verdade (expressão da coisa em sua materialidade). Deixar de acreditar na imagem como mentira e passar a perceber a verdade como imagem, "pôr em movimento o pensamento, como o cinema põe a imagem" (DELEUZE, 2013, 78). Montar é, ao mesmo tempo, operar um corte e um ajuntamento.

Antes de montar é preciso rasgar o que se tem. Esticar até que se cinda, para depois costurar da sua maneira. Praticar o gesto de interrupção (LARROSA, 2014), romper com a política do pronto, do acabado, do dado. Abrir o tecido, para que despontem os fios soltos de memórias (CUSICANQUI, 2015): aqueles que o saber colonial não pôde cooptar, explicar, significar ou interpretar. Que estão livres para receber significações outras, para serem outros modos de existir, uma contra-política. Este é o momento que a política age: no ponto crucial do transitório.

Colocar sobre a mesa as coisas que foram coletadas e finalmente podem ser articuladas. Quem rasga pensa antes de rasgar, antevê o que se precisa ser rasgado e usa o próprio corpo como máquina de operação do rasgo: a mão que estilhaça o graveto em farpas, o dente da criança que quebra o confeito, os dedos que rasgam o papel em dois, depois em quatro... Antes de tudo, o rasgo é uma operação sensorial e empírica. Não há metodologias de rasgo, somente suspeitas. Não é incomum ouvir quem rasga dizer: acho que deveria rasgar aqui ou aqui... O montador sabe onde rasgar porque sentiu o que está rasgando. Sentiu as fragilidades de tudo o que não quer usar ainda e as potências do que deve ser utilizado agora. O maloqueiro rasga. Não está preocupado com o preciosismo do conceito. Pega o que lhe convém, o que pode lhe ser útil, o que lhe ajuda a pensar e elaborar aquilo que vê. Guarda tudo aquilo que ainda não serve, que ainda não pode ser utilizado. Agora ele "irá trabalhar nesse material selecionando, concentrando, eliminando, juntando, reunindo as diferenças" (BADIOU, 2015, p. 68).

Depois o que importa é o ' $e$ '. O e que opera como liga para as palavras. Os caminhos inesperados por entre as cavernas da linguagem (BENJAMIN, 2013), agenciadores de sentidos que não estão dados na imagem e sim na visualidade, que não operam por encadeamentos lógicos sucessivos, e sim, permitindo que cada imagem tome, por si só, proeminência no dizer, na ordem do discurso e numa operação de sentidos da relação (DELEUZE, 2013).

A necessidade de estabelecer a conversa entre imagens. É na imagem do e que podemos ser personagens compostos de múltiplos atravessamentos: negro $e$ favelado $e$ bissexual $e$ filho de mãe solteira $e$ militante $e$ poeta... Isso, em oposição a um ou que fixa uma identidade purista: negro ou trabalhador ou bissexual... Este é um e que "penetra e corrompe tudo... arrasta todas as relações. Existem tantas relações quantos $e$, o e não só desequilibra todas as relações, ele desequilibra o ser, o verbo... etc" (DELEUZE, 2013, p. 62).

Quem monta deve se tornar estrangeiro ou criança, gago, desacostumado com a língua para "por um lado, restituir às imagens exteriores seu pleno, fazer com que não percebamos menos, fazer com que as percepção seja igual a imagem, devolver às imagens tudo o que elas têm" (Idem, p. 60), localizar, aos poucos, o contexto e operar relações com outras imagens. Lutar contra os limitadores da 
visualidade, tal e tal armadilhas dos discursos. O Cinema mostra o que mostra (RANCIERE, 2012, p. 20).

Após ter retirado do seu arsenal aquilo que lhe valia por ocasião, o trabalho de quem lê, ou de quem monta é fazer o objeto montado "adquirir uma consistência, sem perder o infinito no qual o pensamento mergulha" (DELEUZE; GUATTARI, 2014, p. 53). Se importar em devolver a imagem tudo aquilo que lhe atravessa, levá-la ao chão dela mesma sem esquecer de "desfazer a linguagem como tomada de poder, fazê-la gaguejar nas ondas sonoras, decompor todo conjunto de ideias" (DELEUZE, 2013, p. 60). A montagem é, então, a constituição das imagens. Porque essas imagens são sempre operações, "relações entre o dizível e o visível, maneiras de jogar com o antes e o depois, a causa e o efeito" (RANCIÈRE, 2012, p. 14), a (des)continuidade. A fabricação de uma certa relação com a imagem, de um certo cinema, está justo na montagem: "não surgiu uma linguagem autenticamente nova até que os cineastas começassem a cortar o filme em cenas, até o nascimento da montagem" (CARRIĖRE, 2015, p. 30). É montando que podemos transformar toda a imagem - um filme, uma fotografia, uma pintura, uma performance, as imagens de TV, todo o resto do que vemos, ouvimos e pensamos - em um objeto próprio e subjetivo: o que contam são as relações produzidas entre as imagens em si mesmas, porque a subjetividade é o atravessamento de múltiplos vetores de constituição, é o próprio arsenal de imagens construídos durante a vida.

"Eis a força do cinema. Não é construir e a seguir desconstruir, bem entendido, mas ambos ao mesmo tempo" (BADIOU, 2015, p. 51). Por isso falamos em experiências híbridas. Junções profanadoras de tempos e restos, do trabalho das impurezas e do que sobra das outras linguagens: o cinema não é teatro ou somente música, não é somente fotografia ou literatura, muito menos todas elas juntas. O cinema como junção de diversos reais e virtuais, como articulação de possibilidades infinitas de ser e estar no mundo produzindo um outro mundo, um outro espaço e tempo. Não seria correto dizer que a tentativa da educação é a mesma? Nasce, portanto, para nós, a possibilidade de um terceiro modo de presença do Cinema-Educação.

\section{CINEMA-EXPERIÊNCIA E O DESEJO DE UMA MONTAGEM MALOQUEIRA NA EDUCAÇÃO.}

Em certas experiências híbridas de Cinema-Educação vemos a possibilidade de um terceiro modo de presença: o Cinema-Experiência com seu desejo de montar como o maloqueiro monta. Por isso retomamos nossa questão: a que tipo de imagem nosso conhecimento dá a ver?

Ora, podemos dizer que os conhecimentos didáticos dão a ver certa imagem "chapada", branda, unívoca, que só pode dizer uma coisa, fadada a representar. Uma imagem que obrigatoriamente ensina somente aquilo a que foi destinada dizer. O maloqueiro nos instiga: há sempre uma outra possibilidade, uma maneira subversiva de ler as mesmas questões. E mais: existe um mundo não objetivo ou objetificado na imagem, que só pode ser visualizado sob a ótica da política, ou seja, sob a ótica do local e das disputas narrativas que fazemos em torno dos desejos que temos. $O$ maloqueiro talvez nos questione se ainda podemos desejar: seja em educação ou em cinema. Assim, mesmo na escola de contexto normatizador, o Cinema-Experiência insurge como possibilidade 
desterritorialização. Por isso dizemos experiências híbridas. Não se trata somente de duas práticas concomitantes que não se harmonizam, mas da vivência simultânea de dois regimes de tempo e pensamento distintos.

Por outro lado, também, não temos pretensão de alimentar uma reserva moral ou um lugar especial para nós. Convenhamos que a frase "cinema como experimentação do pensamento" soa bem aos nossos ouvidos logocêntricos. Pretendemos um exercício menor, com uma imagem menor. Borrada, rasurada, que não espera as grandes revoluções imagéticas. Pensar por imagens é um exercício mais simples do que se espera: é estar aberto a criação de conceitos, narrativas e ações corriqueiras com a imagem. Um Cinema-Educação feito nem só por professores, nem só por cineastas. Quem faz Cinema-Experiência é amador. O amadorismo é também uma posição teórica e política, a que recusa a autoridade dos especialistas... a política do amador afirma que o cinema pertence a todos aqueles que, de uma ou de outra maneira, viajaram dentro do sistema de desvios que esse nome instaura" (RANCIĖRE, 2012, p. 16).

Aqueles que não dominam a gramática podem corroê-la por dentro, tensionar um pouco mais seus limites. Não estão ligados pelo mercado de trabalho ou pela moda, pelo academicismo e menos ainda pelo compromisso moral ou pelos ditos direitos de aprendizagem. O amadorismo se liga via experiência como acontecimento pouco explicável, pela formação do gosto, do desejo e do prazer. Como nos maloqueiros, o risco do real corporifica as relações com a imagem, as tornam mais possíveis e ao mesmo tempo mais experimentais. Por ser um exercício político de dar a ver outros mundos e outras possibilidades de mundo, o Cinema-Experiência requer a coragem da verdade que o maloqueiro nos mostrou.

\section{REFERÊNCIAS}

1. BADIOU, Alain. O cinema como experimentação filosófica. In: YOEL, Gerrardo (org). Pensar o cinema: imagem, ética e filosofia. São Paulo: Cosac Naify, 2015, p. 31-82.

2. BADIOU, Alain; TRUONG, Nicolas. Elogio ao Amor. São Paulo: Martins Fontes, 2013.

3. BENJAMIN, Walter. O anjo da história. Belo Horizonte: Autêntica Editora, 2012.

4. Imagens de pensamento/ Sobre haxixe e outras drogas. Belo Horizonte: Autêntica Editora, 2013.

5. CARRIĖRE, Jean-Claude. A linguagem secreta do cinema. Rio de Janeiro: Nova Fronteira, 2015.

6. COUTINHO, Mário. Introdução II: Jean-Luc Godard ou pedagogia do Não. In: COUTINHO, Mário; MAYOR, Ana. Godard e a Educação. Belo Horizonte: Autêntica Editora, 2013, p. 19-26. 
7. CUSICANQUI, Silvia; SANTOS, Boaventura. Conversas del mundo. In: SANTOS, Boaventura. Revueltas: de indignación y otras conversas. Bolívia: Stigma. 2015, p. 85-124.

8. DELEUZE, Gilles. Conversações. São Paulo: Editora 34, 2013.

9. DELEUZE, Gilles; GUATTARI, Félix. Por uma literatura menor. Belo Horizonte: Autêntica Editora, 2014.

10. DIDI-HUBERMAN, Georges. Quando as imagens tocam o real. Pós: Belo Horizonte, v. 2, n. 4, p. 204-219, nov. 2012.

11. DUARTE, Rosália; MILENE, Gusmão; FRESQUET, Adriana; TEIXEIRA, Inês; COSTA, Raquel. Mulheres em rede: memórias entre cinema e educação. In: D' ÂNGELO, Raquel; D'ÂNGELO, Fernanda. CineOP: $13^{\circ}$ Mostra de Cinema de Ouro Preto. Belo Horizonte: Universo Produção, $1^{\circ}$ edição, 2018.

12. FANON, Frantz. Os condenados da terra. Juiz de Fora: Ed. UFJF, 2013.

13. FANTIN, Monica. Cinema, Participação Estética e Imaginação. Revista Pedagógica UNOCHAPECÓ: n. 30, vol. 01 - jan./jun. 2013.

14. FOUCAULT, Michel. O Anti-Édipo: uma introdução à vida não fascista. Cadernos de Subjetividade / Núcleo de Estudos e Pesquisas da Subjetividade do Programa de Estudos Pós-Graduados em Psicologia Clínica da PUC-SP. - v. 1, n. 1 (1993) - São Paulo, 1993, p. 197 a 200.

É inútil revoltar-se? Machine Deleuze, 2017. Disponível em: <https://machinedeleuze.wordpress.com/2017/04/08/e-inutil-revoltar-se-por-michel-foucault/>.

16. FRESQUET, Adriana. Cinema e Educação: reflexões e experiências com professores e estudantes da educação básica, dentro e "fora" da escola. Belo Horizonte: Autêntica Editora, 2017.

17. FRESQUET, Adriana; PEREIRA, Geraldo. Escola: memórias do futuro. In: D' ÂNGELO, Raquel; D'ÂNGELO, Fernanda. CineOP: $13^{\circ}$ Mostra de Cinema de Ouro Preto. Belo Horizonte: Universo Produção, $1^{\circ}$ edição, 2018.

18. LARROSA, Jorge. Tecnologias do eu e educação. In: Silva, Tomaz Tadeu. O sujeito da educação. Petrópolis: Vozes, 1994, p.35-86. 
20. MESQUITA, Rui. Da Mediação à Articulação Pedagógica: uma contribuição desde a mandinga para a descolonização da educação. Recife: 2019, no prelo.

21. MIGLIORIN, Cezar. Inevitavelmente Cinema: educação, política e mafuá. Rio de Janeiro: Beco do Azougue, 2015.

22. MOLLETA, Alex. Fazendo cinema na escola: arte audiovisual dentro e fora da sala de aula. São Paulo: Summus Editorial, 2014.

23. RANCIĖRE, Jacques. O destino das imagens. Rio de Janeiro: Contraponto, 2012. . As distâncias do cinema. Rio de Janeiro: Contraponto, 2012.

25. SONTAG, Susan. Sobre a fotografia: ensaios. Rio de Janeiro: Companhia das Letras, 1977.

THOMAZ, Cristiane; MATTOS, Marcelo. Genero e sexualidade na sala de aula: o uso cinema como recurso pedagógico. Interfaces da Educação, Paranaíba, v.6, n.17, p.219-246, 2015.

27. VIEIRA, Rogéria; VELEZ, Fátima. O contributo do cinema para a educação geográfica: um recurso didático em Geografia das migrações. Portugal: GOT, n.o 9 - Revista de Geografia e Ordenamento do Território. Junho de 2016.

\section{Thiago dos Santos Antunes da Silva}

Graduado em Pedagogia pela Universidade Federal de Pernambuco (UFPE) e Mestre em Educação pelo Programa de Pós-graduação em Educação (PPGE-UFPE). Pesquisador vinculado ao Núcleo de Estudos e Pesquisas em História da Educação e Ensino de História de Pernambuco (NEPHEPEUFPE) (desde 06/2016) e ao Grupo de Estudos e Pesquisas Michel Foucault e Educação: Reverberações e Ensaios de Pensamento (GEFPE-UFPE) (desde 03/2016). Membro atuante do Laboratório de Inovações Políticas em Práticas Educativas (LaButuca). Realiza, também, pesquisas sobre Ensino de História; Cinema-Experiência em um viés da Filosofia da Educação e a pedagogia de projetos nas suas reverberações.

\section{Karina Mirian da Cruz Valença Alves}

Doutora em Educação pela Universidade Federal de Pernambuco (UFPE), instituição de onde é professora efetiva com dedicação exclusiva do Departamento de Métodos e Técnicas de Ensino e professora permanente do Programa de Pós-Graduação em Educação (PPGE-UFPE). Tem experiência na área de Educação, com ênfase em Fundamentos da Educação, Currículo e Docência. Atualmente, tem realizado estudos acerca das relações gênero-educação, com especial interesse 
acerca da subjetivação de gênero como efeito das Pedagogias Culturais, tais como o cinema, bem como pesquisado sobre a feminização da Pedagogia a partir do enfoque das teorias curriculares póscríticas e dos estudos feministas.

\section{Maria Thereza Didier de Moraes}

Professora Associada da Universidade Federal de Pernambuco e coordenadora do Núcleo de Estudos e Pesquisas sobre História da Educação e Ensino de História de Pernambuco (NEPHEPE) situado no Centro de Educação da UFPE. Mestrado em História pela Pontifícia Universidade Católica de São Paulo (1994) e Doutorado em Letras (Teoria Literária e Literatura Comparada) pela Universidade de São Paulo (2004). Atua no Mestrado Profissional em Ensino de História da UFPE e trabalha com História, Ensino de História, Literatura, Cinema e Educação dando ênfase nas questões da experiência estética e formação. Atualmente tem se dedicado aos estudos dos entrelaçamentos entre Cinema e Educação.

\section{Como citar este documento:}

ANTUNES DA SILVA, Thiago dos Santos; ALVES, Karina Mirian da Cruz Valença; MORAES, Maria Thereza Didier de. Cinema-experiência e os encontros da imagem com a educação. Reflexão e Ação, Santa Cruz do Sul, v. 28, n. 2, jun. 2020. ISSN 1982-9949. Disponível em: $<$ https://online.unisc.br/seer/index.php/reflex/article/view/14431>. Acesso em: doi:https://doi.org/10.17058/rea.v28i2.14431. 